\title{
Glacial discharge into the subarctic Northeast Pacific Ocean during the last glacial
}

${ }^{1}$ School of Geography, University of Nottingham, University Park, Nottingham, NG7 2RD, UK.

Corresponding author: George Swann (george.swann@nottingham.ac.uk)

\section{Abstract}

Understanding the response of the climate to abrupt changes in the Earth system represents a key objective in paleoclimatology. Heinrich events in the last glacial, during which significant amounts of glacial discharge entered the North Atlantic Ocean, triggered the development of colder conditions across much of the globe. Despite widespread documentation of these events, including their occurrence and global significance, the impact of Heinrich events on the North American Cordilleran Ice Sheet and subarctic North Pacific Ocean remains relatively unconstrained. Here, records of diatom oxygen isotopes are used to show that significant amounts of glacial discharge from the Cordilleran Ice Sheet were released into the open waters of the northeast Pacific Ocean throughout the last glacial. Based on the available age model, many of these episodes and calculated changes in sea surface salinity coincide with Heinrich events. If accurate, these findings would confirm that ocean-atmospheric teleconnections linked the North Atlantic and North Pacific Oceans during intervals of abrupt change in the last glacial, as well as indicating the wider susceptibility of regional ice-sheets to global alterations in the climate system.

Keywords: Diatom, Isotope, Heinrich, Cordilleran Ice Sheet, Salinity

\section{Introduction}

Glacial discharge into the marine system has the potential to exert a major influence on the climate through changes in ocean circulation and carbon dynamics (Menviel et al. 2014). Of particular note are Heinrich events which, triggered by the collapse of the Laurentide Ice Sheet (LIS) into the North Atlantic Ocean during the last glacial, sufficiently reduced North Atlantic surface waters density to initiate a slowdown in Atlantic meridional overturning circulation (AMOC) (Böhm et al., 2015) and cause global changes to the climate system (Clement and Peterson, 2008). Previous research has suggested that the subarctic North Pacific Ocean and North Atlantic Ocean were closely coupled during Dansgaard-Oeschger events in the last glacial as well as over the abrupt climate transitions that accompanied the Last Glacial-Interglacial Transition (LGIT) (Kiefer et al., 2001; Praetorius and Mix, 2014). However, less is known about the extent to which North Atlantic Heinrich events are also associated with concordant changes in the subarctic North Pacific Ocean. 
Sediment cores from the coastal northeast Pacific Ocean document increased IRD from regional glacials during North Atlantic Heinrich events 1 and 5, suggesting that the melting/collapse of the LIS into the North Atlantic Ocean was concordant with similar discharge from the Cordilleran Ice Sheet (CIS) (Cosma and Hendy, 2008; Hendy and Cosma, 2008). However, the magnitude and wider impact of this discharge from the CIS has, until recently, been unclear with oxygen isotope ratios $\left(\delta^{18} \mathrm{O}\right)$ of planktonic foraminifera $\left(\delta^{18} \mathrm{O}_{\text {foram }}\right)$ from near and off-shore open water sites in the northeast Pacific Ocean failing to show the decline in $\delta^{18} \mathrm{O}_{\text {foram }}$ that would be expected were glacial discharge from the CIS to extend beyond the coastal margin (McDonald et al., 1999; Gebhardt et al., 2008; Davies et al., 2011; Taylor et al., 2014; Maier et al., 2015; Praetorius et al. 2015). Recent work, however, has documented decreases in diatom $\delta^{18} \mathrm{O}\left(\delta^{18} \mathrm{O}_{\text {diatom }}\right)$ at site SO202-27-6 in the northeast Pacific Ocean (Figure 1) that are consistent with significant volumes of glacial discharge from the CIS being injected into the open water environment of the subarctic North Pacific Ocean at times, over the last $50 \mathrm{ka}$, that are synchronous with North Atlantic Heinrich events (Maier et al., 2018).

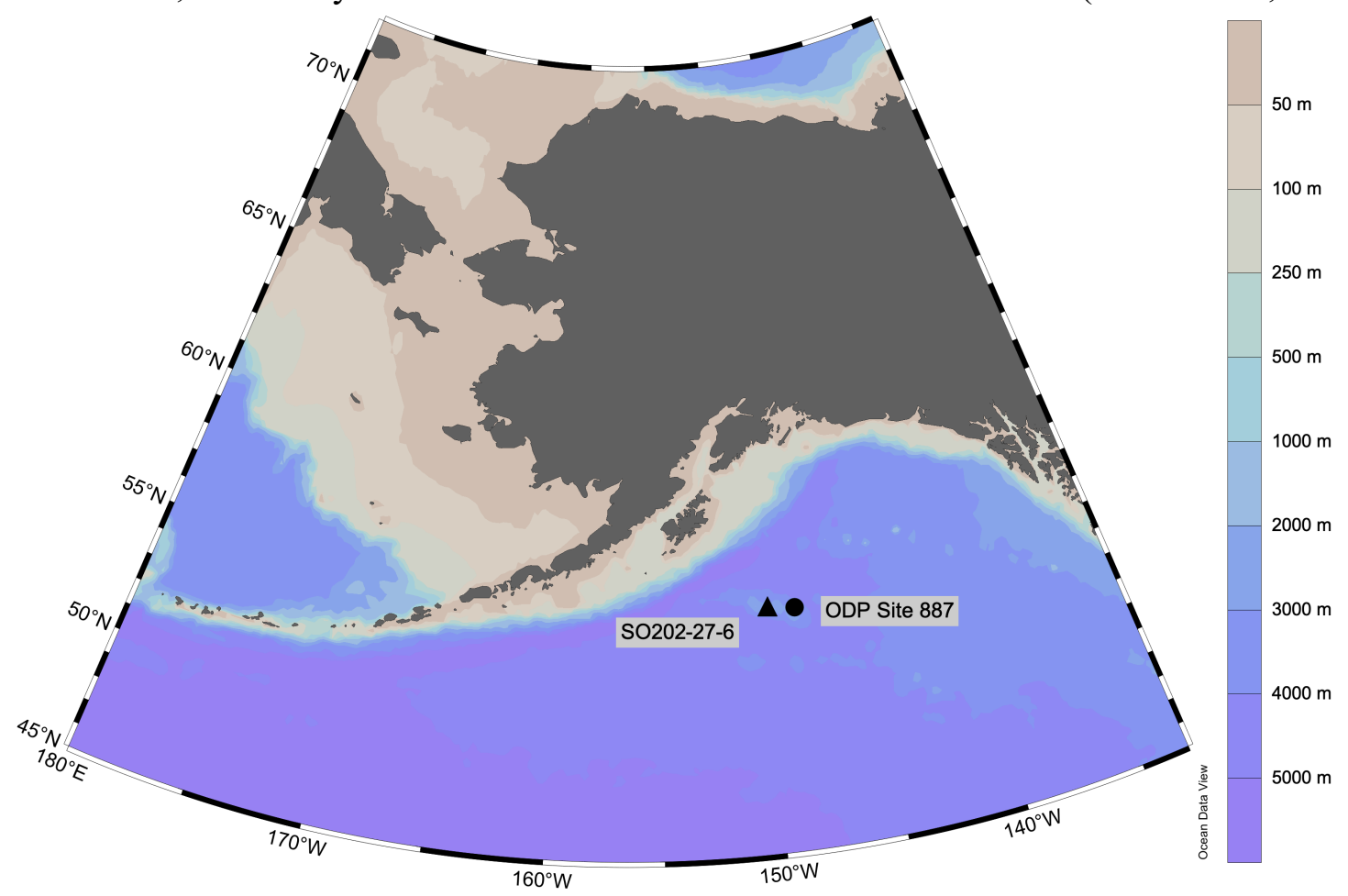

Figure 1. Location of ODP Site $887\left(54.3655^{\circ} \mathrm{N}, 148.4460^{\circ} \mathrm{W}\right)$ and $\mathrm{S} 0202-27-6\left(54.2962^{\circ} \mathrm{N}\right.$ $\left.149.6002^{\circ} \mathrm{W}\right)$ in the northeast subarctic Pacific Ocean. Colours indicate sea floor depth. Map created using Ocean Data View (https://odv.awi.de)

The reductions in sea surface salinity (SSS) associated with these North Pacific glacial discharge events are significant (c. 2-4 psu) and have been linked to a weakened AMOC during a Heinrich event, triggering a series of ocean-atmospheric interactions that warmed sea surface temperatures (SST) along the northeast Pacific Ocean coastline and increased basal melting/calving of the CIS (Maier et al., 2018). Importantly, model simulations suggest that the freshening associated with these events in the North Pacific Ocean was restricted to the uppermost sections of the water 
column where diatoms undergo photosynthesis, not at the lower depths in the surface ocean occupied by planktonic foraminifera (Maier et al., 2018). Such a feature is proposed to account for why a corresponding decline is not apparent in $\delta^{18} \mathrm{O}_{\text {foram }}$ records from sites in the region. It also builds on previous comparisons of $\delta^{18} \mathrm{O}_{\text {diatom }}$ and $\delta^{18} \mathrm{O}_{\text {foram }}$ records across the globe, which reveal distinct differences between the two proxies (Haug et al., 2005; Swann, 2010; Romero et al., 2011; Maier et al., 2015, 2018). Verification of the $\delta^{18} \mathrm{O}_{\text {diatom }}$ inferred SSS changes of 2-4 psu are also tentatively supported by dinocyst assemblage SSS variations of up to c. 3 psu during the last glacial, with the onset of a prolonged freshening event potentially coinciding with Heinrich events 0 at c. 13 ka (de Vernal and Pedersen, 1997; Marret et al., 2001).

Evidence of a teleconnection between the North Atlantic and subarctic North Pacific Oceans during Heinrich events has implications for understanding the paleoclimatology of the last glacial as well as the response of the Earth system to abrupt environmental change. For example, do changes in the AMOC also impact the stability of the CIS over other timescales prior to Heinrich event 5 (c. 45 ka)? How does the teleconnection of the Heinrich events into the North Pacific Ocean impact wider oceanographic and biogeochemical cycling across the subarctic Pacific region including the Bering Sea? These questions fit within a framework in which changes in the subarctic Pacific Ocean are increasingly seen to have played a key role in driving global climate change over glacial-interglacial cycles (Gebhardt et al., 2008; Rae et al., 2014; Du et al., 2018; Gray et al., 2018). In an effort to further document the paleoenvironmental history of the region, an extended $\delta^{18} \mathrm{O}_{\text {diatom }}$ record is presented here from ODP Site 887 in the northeast Pacific Ocean to evaluate the stability of the CIS through the last glacial.

\section{Materials and Methods}

\subsection{ODP Site 887}

ODP Site $887\left(54.3655^{\circ} \mathrm{N}, 148.4460^{\circ} \mathrm{W}\right)$ lies below the Alaska Gyre on the Patton-Murray seamounts c. $300 \mathrm{~km}$ south-east of the Alaskan Shelf at a water depth of 3,647 m (Figure 1). As such the site is close to core SO202-27-6 previously analysed by Maier et al. (2018) which provided the initial $\delta^{18} \mathrm{O}_{\text {diatom }}$ evidence for significant glacial discharge from the CIS into the open waters of the northeast Pacific Ocean during Heinrich events (Figure 1). A composite age-depth model for ODP

2
Site 887 was previously created by splicing missing intervals for the ODP 887B profile from cores ODP Site 887A and 887C using correlation between high-resolution GRAPE and magnetic susceptibility data and with "instantaneous" events (ash layers, turbidites) excluded to create a final “composite depth - ash layer" model (Rae et al 1993; McDonald et al 1999).

86

Existing radiocarbon dating for ODP Site 887 have been measured on planktonic foraminifera 
by McDonald et al. (1999) and Galbraith et al. (2007) (Supplementary Table 1). Here, these dates are

4
combined to create a Bayesian radiocarbon age model for the uppermost sediment using $\mathrm{R}$ (version 4.0.2; R Core Team, 2020) and the Bchron package in which a non-parametric chronology is used to age/position dates following the Compound Poisson-Gamma model (version 4.7.1; Haslett and Parnell, 2008). For all samples the Marine20 calibration curve (Heaton et al., 2020) was used, assuming a constant subarctic Pacific Ocean reservoir age of $550 \pm 250 \mathrm{yr}$ (Galbraith et al., 2007). Samples below a "composite depth - ash layer" of 2.94 m (c. $42.8 \mathrm{ka}$ ) were dated using an existing age-model (Galbraith, 2006; Galbraith et al., 2008) in which a benthic foraminifera $\delta^{18} \mathrm{O}$ record from ODP Site 887 (McDonald 1997) was visually matched against the LR04 benthic stack foraminifera $\delta^{18} \mathrm{O}$ record (Lisiecki and Raymo, 2005).

\subsection{Diatom oxygen isotope analysis}

Over the past 15 years, significant effort has been devoted towards developing and applying $\delta^{18} \mathrm{O}_{\text {diatom }}$ in paleoenvironmental reconstructions. Reflecting the isotopic composition of ambient water $\left(\delta^{18} \mathrm{O}_{\text {water }}\right)$ and with environmental controls similar to those for carbonates such as $\delta^{18} \mathrm{O}_{\text {foram}}$, $\delta^{18} \mathrm{O}_{\text {diatom }}$ represents an important source of information in localities where carbonates are poorly preserved (Swann and Leng, 2009). Forty two samples from ODP Site 887 were prepared for $\delta^{18} \mathrm{O}_{\text {diatom }}$ following Swann et al. (2013), in which a combination of $5 \% \mathrm{HCl}$ and $30 \% \mathrm{H}_{2} \mathrm{O}_{2}$ are used alongside sodium polytungstate in heavy liquid separation at specific gravities of c. $2.2 \mathrm{~g} / \mathrm{ml}$ to remove non-diatom contaminants. After sieving at $75 \mu \mathrm{m}$ to isolate any remaining clay particles with the $>75 \mu \mathrm{m}$ fraction retained for analysis. Prior to analysis samples were screened using a Zeiss Axiovert $40 \mathrm{C}$ inverted microscope, scanning electron microscope (SEM) and X-ray fluorescence (XRF) to confirm sample purity and the absence of non-diatom contaminants. Samples were analysed for $\delta^{18} \mathrm{O}_{\text {diatom }}$ using a step-wise fluorination procedure at the NERC Isotope Geosciences Facility based at the British Geological Survey (Leng and Sloane, 2008). Isotope measurements were made on a Finnigan MAT 253 and converted to the Vienna Standard Mean Ocean Water (VSMOW) scale using the within-run laboratory diatom standard $\mathrm{BFC}_{\text {mod }}$ calibrated against NBS28.

\subsection{Salinity reconstructions}

To estimate changes in SSS, the $\delta^{18} \mathrm{O}$ of local surface seawater $\left(\delta^{18} \mathrm{O}_{\mathrm{ssw}}\right)$ was calculated following the marine $\delta^{18} \mathrm{O}_{\text {diatom }}$ calibration of (Juillet-Leclerc and Labeyrie, 1987):

$$
\text { Local } \delta^{18} \mathrm{O}_{\mathrm{ssw}}=\delta^{18} \mathrm{O}_{\text {diatom }}-34-\sqrt{122-5 \cdot \mathrm{SST}}-\operatorname{mean}\left(\delta^{18} \mathrm{O}_{\mathrm{sw}}\right)
$$

Whilst other calibration exists, Juillet-Leclerc and Labeyrie (1987) remains the most recently validated $\delta^{18} \mathrm{O}_{\text {diatom }}$ calibration for the marine environment and is consistent with the approach used by Maier et al (2018) in their SSS reconstructions. SST was obtained from the linear interpolations 
of dinocyst assemblages August SST data from ODP Site 887, after recalculating samples ages using the age model developed in this current study (Marret et al., 2001). Values of mean $\left(\delta^{18} \mathrm{O}_{\text {sw }}\right)$ accounts for the modern $\delta^{18} \mathrm{O}_{\text {ssw }}$ in the region of $-0.5 \%$ (Kipphut, 1990) and changes in global ice volume using the stacked benthic $\delta^{18} \mathrm{O}_{\text {foram }} \mathrm{LR} 04$ record (Lisiecki and Raymo, 2005).

Values of SSS were then calculated from local $\delta^{18} \mathrm{O}_{\text {ssw }}$ using a linear regression between two end-members states, proposed by Maier et al. (2018), of glacial subsurface water $\left(\delta^{18} \mathrm{O}=0.71 \%\right.$; salinity $=34.29 \mathrm{psu})$ and modern CIS glaciers (-20\%) (Epstein and Sharp, 1959; Kipphut, 1990). The uncertainty associated with both $\delta^{18} \mathrm{O}_{\text {diatom, }}$ SST and its impact on SSS was calculated using Monte Carlo simulations (10,000 replicates) with the Monte Carlo package in R (Leschinski, 2019; R Core Team, 2020), assuming a normal distribution for data uncertainty. Changes in SSS were reconstructed using both the $\delta^{18} \mathrm{O}_{\text {diatom }}$ data presented here and the $\delta^{18} \mathrm{O}_{\text {diatom }}$ data in Maier et al. (2018), in order to check for consistency between the two studies.

The new Bayesian age-model for ODP Site 887 places the start of MIS 1 at $0.49 \mathrm{~m}$ and MIS 2 at $1.98 \mathrm{~m}$ (Figure 2). Diatoms in the analysed isotope samples are dominated by a single taxa Coscinodiscus oculus-iridis. With C. oculus-iridis blooming throughout the year, the $\delta^{18} \mathrm{O}_{\text {diatom }}$ record is interpreted as recording mean annual conditions with a bias towards autumn-spring months when diatom productivity peaks (Takahashi 1986). Over the analysed interval, replicate analysis of sample material indicates a mean analytical reproducibility for $\delta^{18} \mathrm{O}_{\text {diatom }}$ of $0.2 \%$. From $12.8 \mathrm{ka}$ to $107.9 \mathrm{ka}$ $\delta^{18} \mathrm{O}_{\text {diatom }}$ ranges from $39.3 \%$ to $46.5 \%$ (Figure 3a; Supplementary Table 2). Notable variation is apparent in the $\delta^{18} \mathrm{O}_{\text {diatom }}$ record over the analysed interval with major declines at $12.8 \mathrm{ka}, 37.3-40.7$ ka, 50.0-51.5 ka, 68.1-69.5 ka, 90.9 ka, 94.4-95.6 ka and 98.0-107.9 ka. Changes in SSS reconstructed from $\delta^{18} \mathrm{O}_{\text {diatom }}$ follow changes in $\delta^{18} \mathrm{O}_{\text {diatom, }}$, recording decrease of 2-4 psu during the major declines mentioned above (Figure 3c).

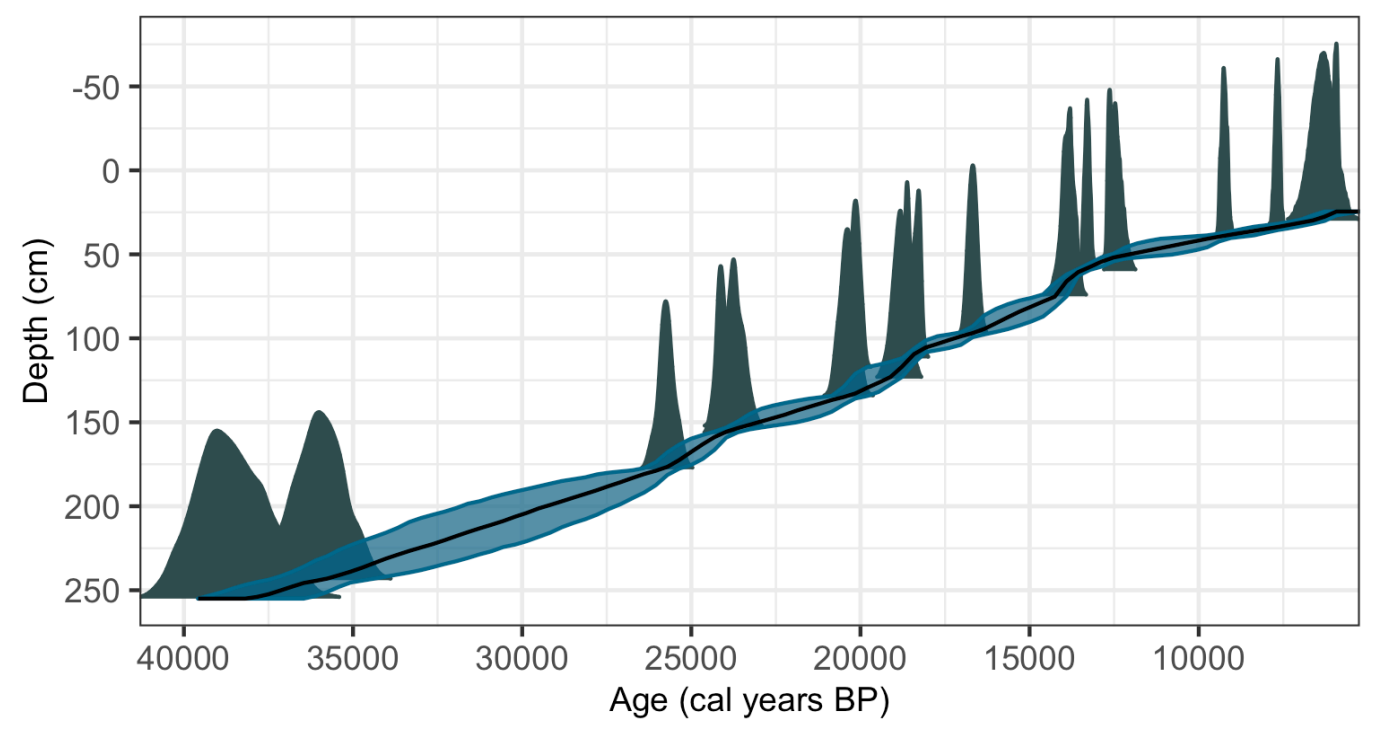


Figure 2. Bayesian age-model for ODP Site 887 combining existing ${ }^{14} \mathrm{C}$ dates (McDonald et al., 1999; Galbraith et al., 2007) with a reservoir age of $550 \pm 250 \mathrm{yr}$ (Galbraith et al., 2007) (Supplementary Table 1). All depths are "composite depth - ash layer" depth.
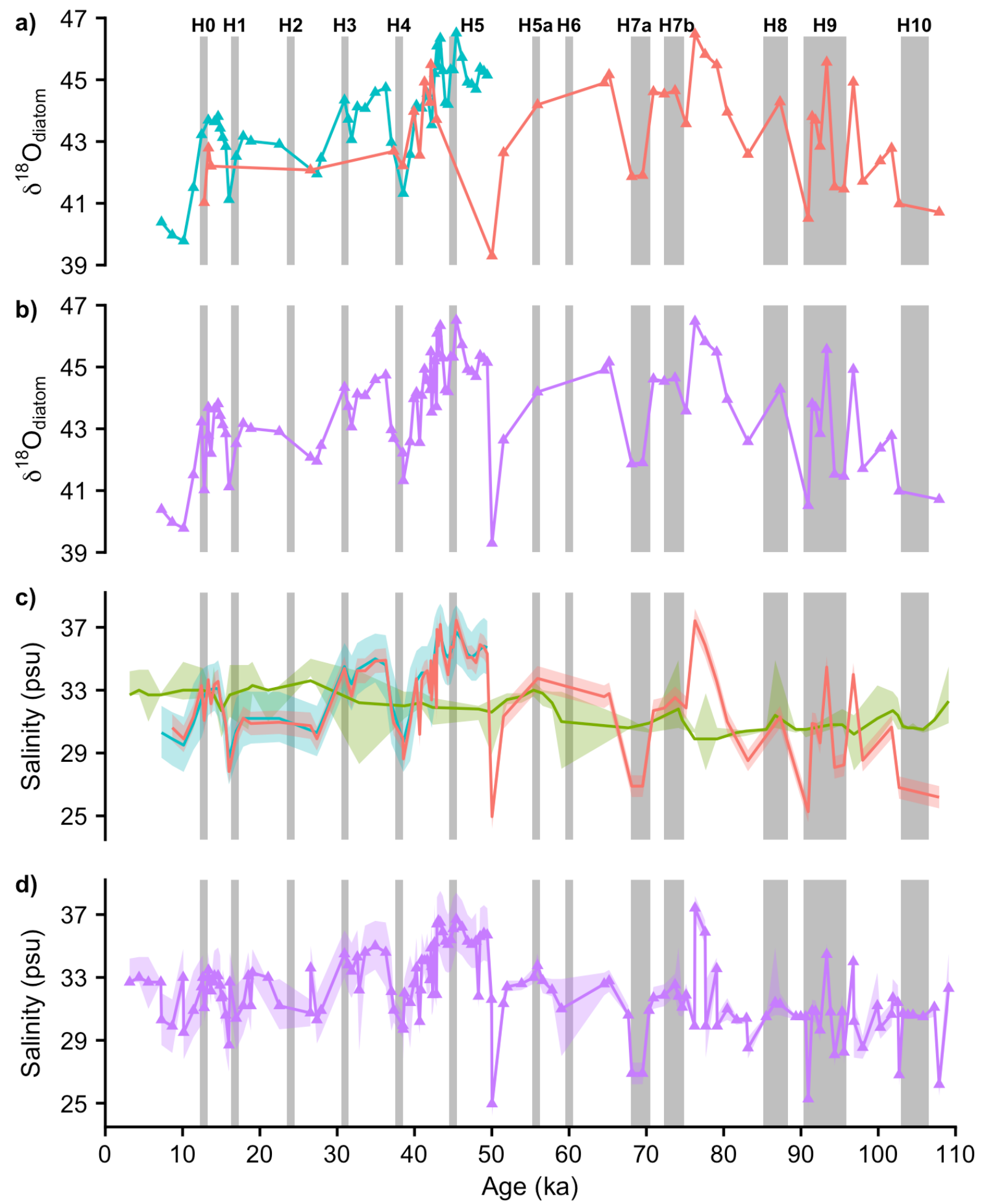

Figure 3. $\delta^{18} \mathrm{O}_{\text {diatom }}$ and salinity reconstructions from the subarctic north east Pacific Ocean. a) $\delta^{18} \mathrm{O}_{\text {diatom }}$ data from ODP Site 887 (this study - red) and site SO202-27-6 (Maier et al., 2018 - blue). b) Composite regional $\delta^{18} \mathrm{O}_{\text {diatom }}$ record for the subarctic northeast Pacific Ocean. c) Reconstructed sea surface salinity in the subarctic northeast Pacific Ocean from $\delta^{18} \mathrm{O}_{\text {diatom }}$ (this study [red], Maier et al., 2018 [blue]) and dinocyst assemblages (Marret et al., 2001: green). d) Composite sea surface salinity after combining original data in panel c (see Supplementary Data). Vertical grey bars indicate the timing of Heinrich events H1-H6 (Hemming (2004) and Channell et al. (2012)) and H7a-H10 (Rasmussen et al (2003)). 


\section{Discussion}

\subsection{Northeast Pacific $\delta^{18} O_{\text {diatom }}$ records}

Within the limits of age model uncertainty, the $\delta^{18} \mathrm{O}_{\text {diatom }}$ record from ODP Site 887 (this study) shows a good similarity to $\delta^{18} \mathrm{O}_{\text {diatom }}$ data from nearby site SO202-27-6 (Maier et al. 2018) during the progressive decline in $\delta^{18} \mathrm{O}_{\text {diatom }}$ from 42.8-37.3 ka as well as during Heinrich events 0 and 4 (Figure 3a). Given the close proximity of sites ODP Site 887 and SO202-27-6 (Figure 1), the fact that oceanographic conditions and photic zone $\delta^{18} \mathrm{O}_{\text {water }}$ are likely to be homogeneous across the region and the similar $\delta^{18} \mathrm{O}_{\text {diatom }}$ results at both sites (Figure 3a), the two $\delta^{18} \mathrm{O}_{\text {diatom }}$ records are merged to create a composite regional $\delta^{18} \mathrm{O}_{\text {diatom }}$ record for the subarctic northeast Pacific Ocean (Figure $3 b$ ). The resultant record reaffirms that decreases in $\delta^{18} \mathrm{O}_{\text {diatom }}$ over the last $50 \mathrm{ka}$ often coincide with Heinrich events (Maier et al., 2018), with further notable declines in $\delta^{18} \mathrm{O}_{\text {diatom }}$ also apparent in the earlier section of the record prior to $50 \mathrm{ka}$ (Figure $3 \mathrm{~b}$ ). In particular, the decreases in $\delta^{18} \mathrm{O}_{\text {diatom }}$ prior to $50 \mathrm{ka}$ at $68.1-69.5 \mathrm{ka}$ and $102.7-107.9 \mathrm{ka}$ are comparable in magnitude to the $\delta^{18} \mathrm{O}_{\text {diatom }}$ decreases observed during Heinrich events 0,1 and 4 as well as coinciding with the timing of Heinrich "type" events 7a and 10 in the Labrador Sea (Rasmussen et al., 2003) (Figure 3b). The interval of abrupt change in $\delta^{18} \mathrm{O}_{\text {diatom }}$ from $90.1-95.6 \mathrm{ka}$, characterized by both high and low $\delta^{18} \mathrm{O}_{\text {diatom }}$ values, is also broadly concordant with Heinrich event 9 (Figure 3b).

Although changes in the amount and $\delta^{18} \mathrm{O}$ ratio of precipitation have the potential to alter photic zone $\delta^{18} \mathrm{O}_{\text {water, }}$, its impact on $\delta^{18} \mathrm{O}_{\text {diatom }}$ is unlikely to be significant (Maier et al., 2018). Given the $7 \%$ range over the last $110 \mathrm{ka}$, the only realistic mechanism to explain the large temporal changes observed in $\delta^{18} \mathrm{O}_{\text {diatom }}$ is glacial discharge from the CIS which is then transported out into the open waters in the region. Whilst $\delta^{18} \mathrm{O}$ end-members for CIS glacial discharge are unknown (Sima et al., 2006), modern CIS glaciers have been measured at c. $-20 \%$ (Epstein and Sharp, 1959; Kipphut, 1990). SSS reconstructed in this study produces results over the analysed interval $(\overline{\mathrm{x}}=32.3 \mathrm{psu}, 1 \sigma$ $=2.8 \mathrm{psu}$ ) that are similar to modern values (32.8 psu: Seidov et al. 2016) and previous salinity reconstructions from the region (de Vernal and Pedersen, 1997; Marret et al., 2001; Maier et al., 2018) (Figure 3c). The recalculation of SSS using $\delta^{18} \mathrm{O}_{\text {diatom }}$ data from Maier et al. (2018) also produces near-identical results, with minor offsets linked to the use here of the LR04 benthic stack Lisiecki and Raymo (2005), rather than Waelbroeck et al. (2002), to account for changes in global ice volume (Figure 3c). Given this, a composite SSS for the region can be created for these individual records, similar to that for $\delta^{18} \mathrm{O}_{\text {diatom }}$ (Figure $3 \mathrm{~d}$ ). During Heinrich events when $\delta^{18} \mathrm{O}_{\text {diatom }}$ decreases (e.g., Heinrich events $0,1,4,6,7 \mathrm{a}$ ) SSS decrease by 2-4 psu, similar to changes seen in the North Atlantic Ocean (Maslin et al., 1995; Chapman and Maslin, 1999) (Figure 3d). However, no consistent change in SSS occurs in other Heinrich events, whilst and other notable changes of 1-2 psu or even greater 
are apparent in other intervals through the last $110 \mathrm{ka}$ (Figure $3 \mathrm{~d}$ ).

\subsection{Stability of the Cordilleran Ice Sheet}

Previous research on cores close to the shoreline/continental margin have demonstrated significant glacier discharge from the CIS over the last $50 \mathrm{ka}$ during Heinrich events 1 and 5 (Cosma and Hendy, 2008; Hendy and Cosma, 2008). At the same time, freshwater diatoms along the coastal northeastern Pacific indicate megafloods during the last glacial that would have lowered SSS by up to $6 \mathrm{psu}$ (Lopes and Mix, 2009). The constraints of the ODP Site 887 age model beyond the ${ }^{14} \mathrm{C}$ dated interval, combined with low sediment opal concentrations, limits the creation of a higher resolution $\delta^{18} \mathrm{O}_{\text {diatom }}$ record as well as the extent to which $\delta^{18} \mathrm{O}_{\text {diatom }}$ and SSS changes in the northeast Pacific prior to $50 \mathrm{ka}$ can be confidently tied to other global records of environmental change. For example, the difficulty in extracting sufficient diatoms for isotope analysis explains the lack of $\delta^{18} \mathrm{O}_{\text {diatom }}$ data for Heinrich event 8 at ODP Site 887 as well as for Heinrich events 5 a and 6 at both site SO202-276 and ODP Site 887 (Figure 3). Despite this, the findings presented here from ODP Site 887 and site SO202-27-6 (Maier et al., 2018) show that throughout the last glacial significant amounts of glacial discharge from the CIS entered the open waters of the North Pacific Ocean and extended beyond the coastal margin, including in intervals dated to both classic Heinrich events (Heinrich events 1-6) and Heinrich "type" events (Heinrich events 7a-10: Rasmussen et al., (2003)).

Significant glacial discharge from the CIS during Heinrich events 1-4 has been attributed to a weakened Atlantic meridional overturning circulation, triggering a southward migration of the Intertropical Convergence Zone and warmer eastern Equatorial Pacific Ocean SST (Maier et al., 2018) (Figure 4). These ocean-atmospheric teleconnections would have then strengthened the Aleutian Low and increased the northward transportation of warm sub-tropical waters to the coastal northeastern North Pacific Ocean, resulting in increased basal melting/calving of the marine-based CIS (Maier et al., 2018). These events could have been triggered by the onset of North Pacific deep water formation and Pacific meridional overturning circulation (PMOC), which has previously been observed during Heinrich event 1. However, debate remains about the prevalence of PMOC during the Younger Dryas and whether ventilation occurred to immediate or lower depths (Okazaki et al., 2010; Chikamoto et al., 2012; Hu et al., 2012; Rae et al 2014; Liu and Hu, 2015; Gong et al., 2019). There is also a lack of studies examining the presence/absence of PMOC during other Heinrich events as well as other abrupt events through the last glacial. 

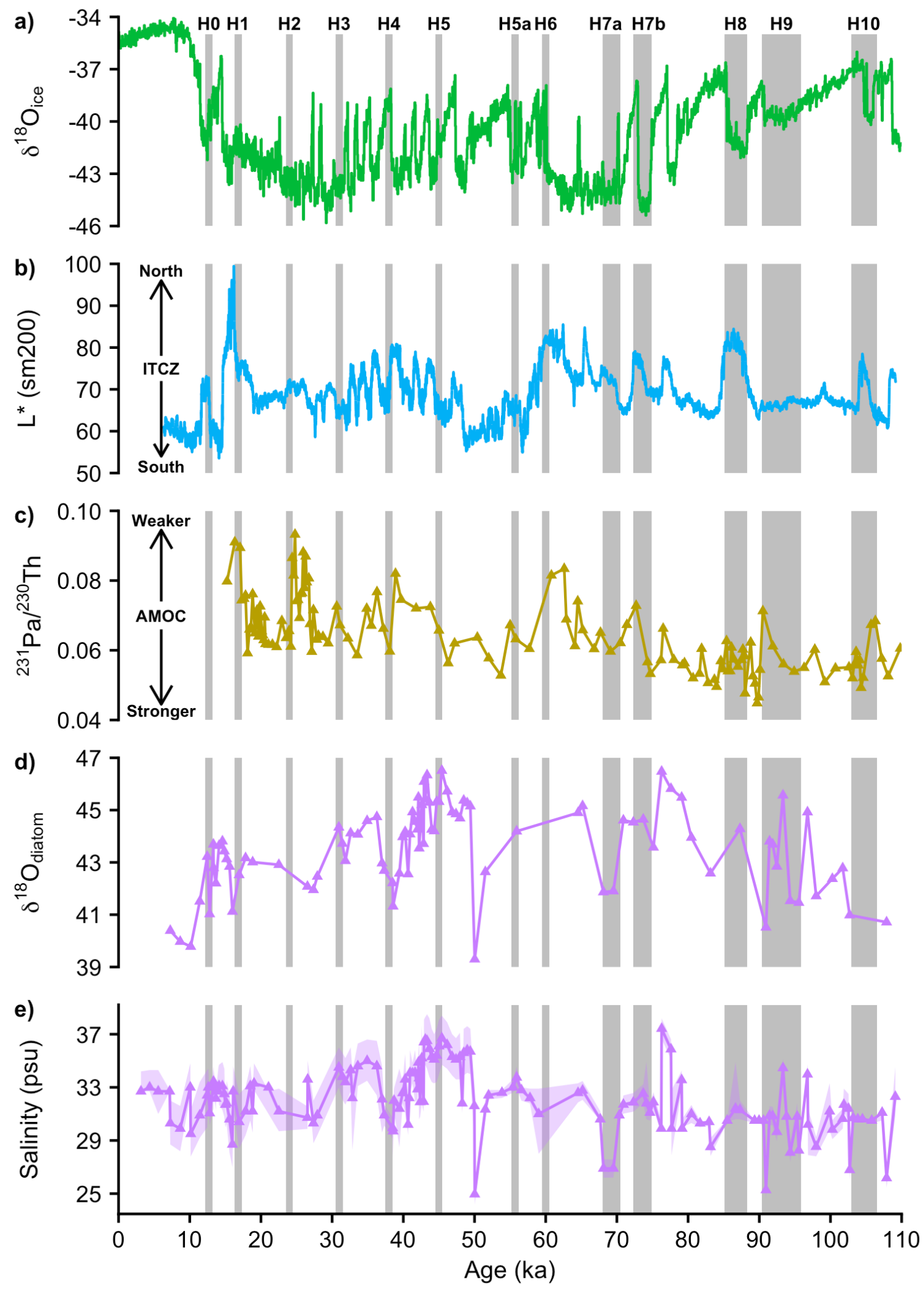

Figure 4. Global drivers of palaeoceanographic change. a) NGRIP ice core $\delta^{18} \mathrm{O}\left(\delta^{18} \mathrm{O}_{\text {ice }}\right)$ (NGRIP Project Members, 2004). b) Intertropical Convergence Zone (ITCZ) inferred from reflectance data in the Cariaco Basin with a 200-point running mean ( $\left.\mathrm{L}^{*}, \mathrm{sm} 200\right)$ (Deplazes et al 2013). c) Changes in the Atlantic meridional overturning circulation (AMOC) $\left.{ }^{(231} \mathrm{Pa} /{ }^{230} \mathrm{Th}\right)$ (Böhm et al. 2015). d) Composite $\delta^{18} \mathrm{O}_{\text {diatom }}$ record for the subarctic northeast Pacific Ocean. e) Composite sea surface salinity reconstructed from $\delta^{18} \mathrm{O}_{\text {diatom }}$ (this study, Maier et al., 2018) and dinocyst assemblages (Marret et al., 2001). Vertical bars indicate timing of Heinrich events H1-H6 (Hemming (2004) and Channell et al. (2012)) and H7a-H10 (Rasmussen et al (2003)). 
The new $\delta^{18} \mathrm{O}_{\text {diatom }}$ data from ODP Site 887 suggests that decreases in $\delta^{18} \mathrm{O}_{\text {diatom }}$ coinciding with Heinrich events $7 \mathrm{a}$ and 10 are also synchronous with a southward shift in the ITCZ (Deplazes et al 2013) (Figure 4), indicating that a set of ocean-atmospheric mechanisms similar to those outlined above may also have linked the North Atlantic and subarctic North Pacific Oceans during the first half of the last glacial prior to $50 \mathrm{ka}$ (Figure 4). This, however, is counteracted by the absence of a: 1) decrease in $\delta^{18} \mathrm{O}_{\text {diatom }}$ during Heinrich event $7 \mathrm{~b} ; 2$ ) southward migration of the ITCZ during the $\delta^{18} \mathrm{O}_{\text {diatom }}$ decreases in Heinrich event 9; 3) significant reduction in AMOC strength throughout the duration of Heinrich events 7-10 (Böhm et al. 2015); and 4) a sustained decrease in SSS during Heinrich events 7b-10). During Heinrich event 3 unusually cold Northern Hemisphere climatic conditions, as indicated by Greenland ice core $\delta^{18} \mathrm{O}\left(\delta^{18} \mathrm{O}_{\text {ice }}\right)$ measurements (NGRIP Project Members, 2004), are argued to have inhibited the northward advection of warm SST waters from the subtropics, reducing basal melting/calving of the CIS (Figure 4) (Maier et al., 2018). Equally cold conditions and a similar negative feedback mechanism, in which the ocean-atmospheric teleconnections triggered by a Heinrich event fails to warm the subsurface northeast Pacific coastline, could also have operated in Heinrich event $7 b$ (Figure 4). Indeed, other core from the North Pacific Ocean fail to show surface warming during abrupt climate reversals over the last 15,000 years, suggesting that any increase in meridional heat transport was not always sufficient to compensate for the shift to cooler climatic conditions across the Northern Hemisphere that occurred during a Heinrich event (Max et al., 2012). However, in contrast to Heinrich events 3 and 7b, this rationale can not be applied to Heinrich events 9 and 10 which were characterized by relatively warm stadial conditions in the Northern Hemisphere (NGRIP Project Members, 2004) (Figure 4).

Whilst it remains unclear how relatively warm conditions in Heinrich events 9 and 10 would have impacted ocean-atmospheric mechanisms linking the CIS/North Pacific region to the North Atlantic Ocean, the different climate state associated with these events may explain the absence of a corresponding, sustained, change in the AMOC and ITCZ. Indeed, evidence exists that some Heinrich events may have only experienced relatively minor changes in AMOC strength (Lynch-Stieglitz et al 2014). Evidence from the last deglaciation has shown the sensitivity of the CIS to regional climate change (Lesnek et al. 2020) and calving of the CIS during Heinrich events has also been tentatively linked to regional atmospheric warming or rising sea-level (Hendy and Cosma, 2008). Whilst the state of these processes during the first half of the last glacial remains unknown, either of these or another variable could be responsible for the: 1) rapid fluctuation and irregular melting of the CIS during Heinrich event 9;2) glacial discharge during the interval broadly covered by Heinrich event 10; and 3) the low, but otherwise unexplained, $\delta^{18} \mathrm{O}_{\text {diatom }}$ values from 50.0-51.5 ka. Further work is needed into not only these intervals, but also into other regional climate changes through the last 
glacial that may be responsible for the 1-2 psu variations that occur outside of Heinrich event age boundaries (Figure 4e).

\subsection{Comparison of $\delta^{18} O_{\text {diatom }} \& \delta^{18} O_{\text {foram }}$}

Planktonic $\delta^{18} \mathrm{O}_{\text {foram }}$ records at ODP Site 887 (Globigerina bulloides - McDonald et al., 1999) and site SO202-27-6 (sinistral Neogloboquadrina pachyderma - Maier et al., 2018) show contrasting changes over the last $50 \mathrm{ka}$ with greater variability apparent at ODP Site 887 (Figure 5). These differences in $\delta^{18} \mathrm{O}_{\text {foram }}$ may be linked to inter-species variations in foraminifera seasonality or depth habitat (Metcalfe et al. 2019). The relative stability of the $\delta^{18} \mathrm{O}_{\text {foram }}$ records, however, is in marked contrast to the highly variable values of $\delta^{18} \mathrm{O}_{\text {diatom }}$ recorded at ODP Site 887 and SO202-27-6 (Figure 5). The lack of variation in $\delta^{18} \mathrm{O}_{\text {foram }}$, relative to $\delta^{18} \mathrm{O}_{\text {diatom, at }} \mathrm{SO} 202-27-6$ has been attributed to $\delta^{18} \mathrm{O}_{\text {foram }}$ reflecting subsurface conditions close to the thermocline, rather than the 'true' surface water conditions given by $\delta^{18} \mathrm{O}_{\text {diatom }}$ (Maier et al., 2015) (Figure 5). This interpretation builds on the increased understanding of foraminifera depth habitats (Iwasaki et al., 2017; Taylor et al., 2018) and can be extended to account for the different trends also observed between $\delta^{18} \mathrm{O}_{\text {foram }}$ and $\delta^{18} \mathrm{O}_{\text {diatom }}$ at ODP Site 887 (Figure 5). However, this is dependent on the assumption that large glacial discharges from the CIS would be capable of generating significant $\delta^{18} \mathrm{O}_{\text {water }}$ changes in the surface waters occupied by diatoms, without triggering a correspondent change in subsurface $\delta^{18} \mathrm{O}_{\text {water }}$ at depths occupied by planktonic foraminifera.

The results from this study and Maier et al. (2018) show clear evidence from $\delta^{18} \mathrm{O}_{\text {diatom, in }}$ conjunction with previously published dinocyst assemblage SSS reconstructions (de Vernal and Pedersen, 1997; Marret et al., 2001), that marked changes in the stability of the CIS occurred over the last $110 \mathrm{ka}$. Although these findings are supported by an isotope-enabled model and hosing experiments which suggest that inputs from the CIS did not alter subsurface $\delta^{18} \mathrm{O}_{\text {water }}$ and so planktonic $\delta^{18} \mathrm{O}_{\text {foram }}$ (Maier et al., 2018), such an event would require an unusually large $\delta^{18} \mathrm{O}_{\text {water }}$ gradient to exist in the water column. A number of other paleoceanographic studies have also documented large differences between Quaternary and Pliocene records of $\delta^{18} \mathrm{O}_{\text {diatom }}$ and planktonic $\delta^{18} \mathrm{O}_{\text {foram }}$ in the North Atlantic (Romero et al., 2011), North West Pacific (Haug et al., 2005; Swann et al., 2006; Swann, 2010) and Southern Oceans (Shemesh et al., 1995, 2002). Although studies over the last two decades have conclusively demonstrated a surface $\delta^{18} \mathrm{O}_{\text {water }}$ signature in $\delta^{18} \mathrm{O}_{\text {diatom, }}$, resulting in $\delta^{18} \mathrm{O}_{\text {diatom }}$ becoming a key proxy in carbonate free sediments, the isotopic systematic of $\delta^{18} \mathrm{O}_{\text {diatom }}$ remain notably less well known than those for $\delta^{18} \mathrm{O}_{\text {foram }}$ (Swann and Leng, 2009). As such, 
it is reasonable to consider whether uncertainty over the systematics of $\delta^{18} \mathrm{O}_{\text {diatom }}$ brings in question the paleoceanographic interpretations made in this study.
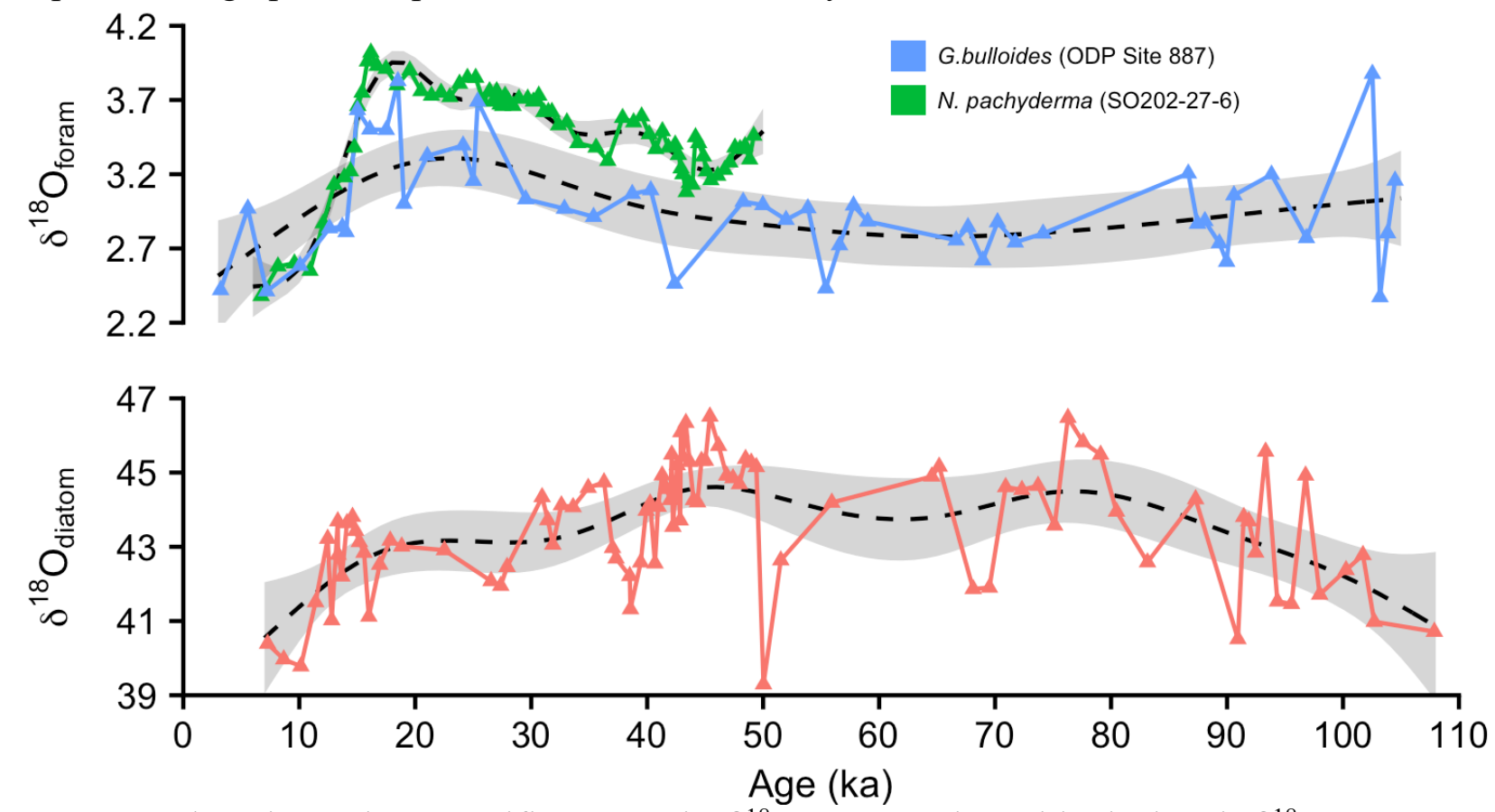

294 Figure 5. Subarctic northeast Pacific composite $\delta^{18} \mathrm{O}_{\text {diatom }}$ together with planktonic $\delta^{18} \mathrm{O}_{\text {foram }}$ at ODP Site 887 (G. bulloides) (McDonald et al., 1999) and SO202-27-6 (sinistral N. pachyderma) (Maier et al., 2018). Black dashed line show a generalized additive model fitted to each time series using using the $m g c v$ package (version 1.8.28; Wood, 2017) in R (version 3.5.2; R Core Team, 2020).

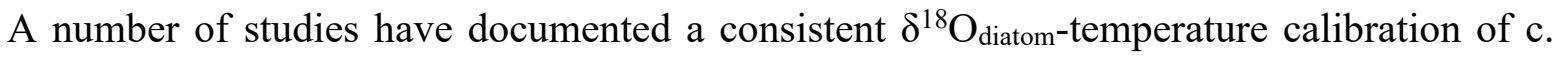
0.2\% $/{ }^{\circ} \mathrm{C}$ (Brandriss et al.,1998; Moschen et al.,2005; Crespin et al., 2010; Dodd and Sharp, 2010; Dong and JingTai, 2010; Dodd et al., 2012). The potential for inter-species differences in diatom $\delta^{18} \mathrm{O}$ fractionation impacting the individual $\delta^{18} \mathrm{O}_{\text {diatom }}$ records at SO202-27-6 and ODP Site 887 can be discounted given that analysed samples are dominated by a single taxa (SO202-27-6 - Coscinodiscus marginatus); ODP Site 887 - C. oculus-iridis). Whilst two studies have indicated a possible interspecies vital effect in $\delta^{18} \mathrm{O}_{\text {diatom }}$ (Swann et al. 2007, 2008), raising questions over the validity of the composite $\delta^{18} \mathrm{O}_{\text {diatom }}$ record created for the subarctic northeast Pacific, numerous other studies have failed to find any evidence of such a process in either culture experiments, sediment traps or downcore records (Sancetta et al., 1985 Juillet-Leclerc and Labeyrie, 1987; Shemesh et al., 1995; Brandriss et al., 1998; Schmidt et al., 2001; Moschen et al., 2005; Schiff et al., 2009; Dodd and Sharp 2010; Chapligin et al., 2012, Bailey et al., 2014; Crespin et al., 2014). More pressing is the debate over the potential for $\delta^{18} \mathrm{O}_{\text {diatom }}$ to be altered by maturation during sedimentation/early burial when dehydroxylation can lead to an increase in $\delta^{18} \mathrm{O}_{\text {diatom }}$ (Schmidt et al., 1997, 2001; Moschen et al., 2005, 2006; Dodd et al., 2012, 2017; Menicucci et al., 2017). On the one hand, it remains unknown to what extent some of the high temporal variability observed in the northeast Pacific Ocean $\delta^{18} \mathrm{O}_{\text {diatom }}$ records, relative to $\delta^{18} \mathrm{O}_{\text {foram }}$ (Figure 5), might be attributable to silica maturation. Whilst this limits 
efforts to accurately quantify the magnitude of glacial discharge using CIS $\delta^{18} \mathrm{O}$ end-members and its impact on both SSS and $\delta^{18} \mathrm{O}_{\text {water }}$ water column profiles, evidence suggests that diatoms from high latitude locations may only experience slow rates of maturation over millions of years (Menicucci et al., 2017) rather than the c. $110 \mathrm{ka}$ covered by this study. Consequently, despite the $\delta^{18} \mathrm{O}_{\text {diatom }}$ record being amplified relative to $\delta^{18} \mathrm{O}_{\text {foram}}$, it is argued that the main finding of this study and Maier et al. (2018) remain valid in providing evidence for a periodically unstable CIS during the last glacial.

\section{Conclusions}

Results here from ODP Site 887, in addition to those from site S0202-27-6 (Maier et al 2018), provide clear evidence of significant glacial discharge from the CIS throughout the last glacial into the open waters of the subarctic northeast Pacific Ocean. Within the limits of age-model accuracy and the low-resolution nature of the $\delta^{18} \mathrm{O}_{\text {diatom }}$ record, these events appear broadly concordant with Heinrich events in the North Atlantic Ocean. Such a coupling would reiterate previous work indicating that a series of ocean-atmospheric teleconnections that linked the North Atlantic and North Pacific Oceans during these abrupt paleoenvironmental events (Maier et al 2018).

Currently, it remains unknown whether the same ocean-mechanisms previously proposed for Heinrich events 1-4 (Maier et al 2018) can be extended to earlier Heinrich "type" events that occurred prior to $50 \mathrm{ka}$. In addition to requiring higher resolution $\delta^{18} \mathrm{O}_{\text {diatom }}$ records with well constrained agemodel from the northeast Pacific Ocean to confirm the magnitude, frequency and timing of past CIS instability, the findings from this study and Maier et al (2018) highlight the need for research that examines the wider impact of these glacial discharge events on regional biogeochemical cycling and oceanographic changes across the subarctic North Pacific Ocean during the last glacial.

\section{Acknowledgments}

This work was supported by the Natural Environment Research Council and a NERC postdoctoral fellowship award to GEAS (grant numbers NE/F012969/1, NE/F012969/2). Thanks are owed to Eric Galbraith for discussions on the ODP Site 887 age-model as well as to Hilary Sloane and Melanie

340 Leng at the NERC Isotope Geosciences Facility (British Geological Survey) for their advice and support with the $\delta^{18} \mathrm{O}_{\text {diatom }}$ analyses. Finally, the constructive comments provided by the editor and reviewers are appreciated as they significantly improved the final version of this paper.

\section{Data availability}

344 On acceptance the data from this paper (see Supplementary Information) will be available from www.pangaea.de. 


\section{Supplementary data}

Table S1. Uncalibrated ${ }^{14} \mathrm{C}$ ages (McDonald et al., 1999; Galbraith et al., 2007) with no correction for reservoir age.

Table S2. Diatom oxygen isotope $\left(\delta^{18} \mathrm{O}_{\text {diatom }}\right)$ data from ODP Site 887.

350 Table S3. Reconstructed sea surface salinity (SSS) from this study [ODP Site 887], Marret et al. (2001) [ODP Site 887] and Maier et al. (2018) (SO202-27-6).

\section{References}

Bailey, H.L., Henderson, A.C.G., Sloane, H.J., Snelling, A., Leng, M.J., \& Kaufman, D.S. (2014). The effect of species on lacustrine $\delta^{18} \mathrm{O}_{\text {diatom }}$ and its implications for palaeoenvironmental reconstructions. Journal of Quaternary Science, 29, 393-400.

Böhm, E., Lippold, J., Gutjahr, M., Frank, M., Blaser, P., Antz, B., Fohlmeister, J., Frank, N., Andersen, M. B., \& Deininger, M. (2015). Strong and deep Atlantic meridional overturning circulation during the last glacial cycle. Nature, 517, 73-76.

Brandriss, M. E., O’Neil, J. R., Edlund, M. B., \& Stoermer, E. F. (1998). Oxygen isotope fractionation between diatomaceous silica and water. Geochimica et Cosmochimica Acta, 62, 1119-1125.

Channell, J. E. T., Hodell, D. A., Romero, O., Hillaire-Marcel, C., de Vernal, A., Stoner, J. S., Mazaud, A., \& Röhl, U. (2012). A 750-kyr detrital-layer stratigraphy for the North Atlantic (IODP Sites U1302U1303, Orphan Knoll, Labrador Sea). Earth and Planetary Science Letters, 317-318, 218-230.

Chapligin, B., Meyer, H., Bryan, A., Snyder, J., \& Kemnitz, H. (2012). Assessment of purification and contamination correction methods for analysing the oxygen isotope composition from biogenic silica. Chemical Geology, 300-301 185-199.

Chikamoto, M. O., Menviel, L., Abe-Ouchi, A., Ohgaito, R., Timmermann, A., Okazaki, Y., Harada, N., Oka, A., \& Mouchet, A. (2012) Variability in North Pacific intermediate and deep water ventilation during Heinrich events in two coupled climate models. Deep-Sea Reseach II, 61-64, 114-126.

Chapman, M. R., \& M. A. Maslin (1999). Low-latitude forcing of merid- ional temperature and salinity gradients in the subpolar North Atlantic and the growth of glacial ice sheets. Geology, 27, 875-887.

Clement, A.C., \& Peterson, L.C. (2008). Mechanisms of abrupt climate change of the last glacial period, Reviews of Geophysics, 46, RG4002, doi:10.1029/2006RG000204.

Cosma, T., \& Hendy, I.L. (2008). Pleistocene glacimarine sedimentation on the continental slope off Vancouver Island, British Columbia. Marine Geology, 255, 45-54.

Crespin, J., Sylvestre, F., Alexandre, A., Sonzogni, C., Pailles, C., \& Perga, M.-E. (2010). Re-examination of the temperature-dependent relationship between $\delta^{18} \mathrm{O}_{\text {diatom }}$ and $\delta^{18} \mathrm{O}_{\text {lakewater }}$ and implications for paleoclimate inferences. Journal of Paleolimnology, 44, 547-557.

Crespin, J., Yam, R., Crosta, X., Massé, G., Schmidt, S., Campagne, P., \& Shemesh, A. (2014). Holocene glacial discharge fluctuations and recent instability in East Antarctica. Earth and Planetary Science Letters, 394 38-47.

Davies, M. H., Mix, A. C., Stoner, J. S., Addison, J. A., Jaeger J., Finney, B., \& Wiest, J. (2011). The deglacial transition on the southeastern Alaska Margin: Meltwater input, sea level rise, marine productivity, and sedimentary anoxia. Paleoceanography, 26, PA2223, doi:10.1029/2010PA002051.

de Vernal, A., \& Pedersen, T.F. (1997). Micropaleontology and palynology of core PAR87A-10: A 23,000 year record of paleoenvironmental changes in the Gulf of Alaska, northeast North Pacific. Paleoceanography, 12, 821-830. 
Deplazes, G., Lückge, A., Peterson, L. C., Timmermann, A., Hamann, Y., Hughen, K. A., Röhl, U., Laj, C., Cane, M. A., Sigman, D. M., \& Haug, G. H. (2013). Links between tropical rainfall and North Atlantic climate during the last glacial period. Nature Geoscience, 6, 213-217.

Dodd, J. P., \& Sharp, Z. D. (2010). A laser fluorination method for oxygen isotope analysis of biogenic silica and a new oxygen isotope calibration of modern diatoms in freshwater environments. Geochimica et Cosmochimica Acta, 74, 1381-1390.

Dodd, J. P., Sharp, Z. D., Fawcett, P. J., Brearley, A. J., \& McCubbin, F. M. (2012). Rapid post-mortem maturation of diatom silica oxygen isotope values. Geochemistry Geophysics Geosystems, 13, Q09014, doi:10.1029/2011GC004019.

Dodd, J. P., Wiedenheft, W., \& Schwartz, J. M. (2017). Dehydroxylation and diagenetic variations in diatom oxygen isotope values. Geochimica et Cosmochimica Acta, 199, 185-195.

Dong, L., \& JingTai, H. (2010). Temperature-induced fractionation of oxygen isotopes of diatom frustules and growth water in Lake Sihailongwan in Northeast China. Chinese Science Bulletin, 55, 3794-3801.

Du, J, Haley, B. A., Mix, A. C., Walczak, M. H., \& Praetorius, S. K. (2018). Flushing of the deep Pacific Ocean and the deglacial rise of atmospheric $\mathrm{CO}_{2}$ concentrations. Nature Geoscience, 11, 749-755.

Epstein, S., \& Sharp, R. P. (1959). Oxygen-isotope variations in the Malaspina and Saskatchewan glaciers. The Journal of Geology, 67, 88-102. Galbraith, E. D. (2006). Interactions between climate and the marine nitrogen cycle on glacial-interglacial timescales. Ph.D. thesis, 228 pp., Univ. of B. C., Vancouver.

Galbraith, E. D., Jaccard, S. L., Pedersen, T. F., Sigman, D. M., Haug, G. H., Cook, M., Southon, J. R., \& Francois, R. (2007). Carbon dioxide release from the North Pacific abyss during the last deglaciation. Nature, 449, 890-894.

Galbraith, E. D., Kienast, M., Jaccard, S. L., Pedersen, T. F., Brunelle, B. G., Sigman, D. M., \& Kiefer, T. (2008). Consistent relationship between global climate and surface nitrate utilization in the western subarctic Pacific throughout the last 500 ka. Paleoceanography, 23, PA2212, doi:10.1029/2007PA001518.

Gebhardt, H., Sarnthein, M., Grootes, P. M., Kiefer, T., Kuehn, H., Schmieder, F. , \& Röhl U. (2008). Paleonutrient and productivity records from the subarctic North Pacific for Pleistocene glacial terminations I to V. Paleoceanography, 23, PA4212, doi:10.1029/2007PA001513.

Gong, X., Lembke-Jene, L., Lohmann, G., Knorr, G., Tiedemann, R., Zou, J.J. \& Shi, X.F. (2019) Enhanced North Pacific deep-ocean stratification by stronger intermediate water formation during Heinrich Stadial. Nature Communications, 10, 656.

Gray, W. R., Rae, J. W. B., Wills, R. C. J., Shevenell, A. E., Taylor, B., Burke, A., Foster, G. L., \& Lear, C. H. (2018). Deglacial upwelling, productivity and $\mathrm{CO}_{2}$ outgassing in the North Pacific Ocean. Nature Geoscience, 11, 340-344.

Haslett, J., \& Parnell, A. C. (2008). A simple monotone process with application to radiocarbon-dated depth chronologies. Journal of the Royal Statistical Society: Series C (Applied Statistics), 57, 399-418.

Haug, G. H., Ganopolski, A., Sigman, D. M., Rosell-Mele, A., Swann, G. E. A., Tiedemann, R., Jaccard, S., Bollmann, J., Maslin, M. A., Leng, M .J., \& Eglinton, G. (2005). North Pacific seasonality and the glaciation of North America 2.7 million years ago. Nature, 433, 821-825.

Heaton, T. J., Köhler, P., Butzin, M,. Bard, E., Reimer, R. W., Austin, W. E. N., Bronk Ramsey, C., Grootes, P. M., Hughen, K. A., Kromer, B., Reimer, P. J., Adkins, J., Burke, A., Cook, M. S., Olsen, J., \& Skinner, L. C. (2020) Marine20-the marine radiocarbon age calibration curve (0-55,000 cal BP). Radiocarbon 62, doi: 10.1017/RDC.2020.68.

Hemming, S. R. (2004). Heinrich events: Massive late Pleistocene detritus layers of the North Atlantic and their global climate imprint. Reviews of Geophysics, 42, RG1005, doi:10.1029/2003RG000128.

Hendy, I. L., \& T. Cosma (2008). Vulnerability of the Cordilleran Ice Sheet to iceberg calving during late Quaternary rapid climate change events. Paleoceanography, 23, PA2101, doi:10.1029/2008PA001606. 
Hu, A., Meehl, G.A., Han, W., Abe-Ouchi, A., Morrill, C., Okazaki, Y., \& Chikamoto, M.O. (2012) The Pacific-Atlantic seesaw and the Bering Strait. Geophysical Research Letters, 39, L03702.

Iwasaki, S., Kimoto, K., Kuroyanagi, A., Kawahata, H. (2017). Horizontal and vertical distributions of planktic foraminifera in the subarctic Pacific. Marine Micropaleontology, 130, 1-14.

Juillet-Leclerc, A., \& Labeyrie, L. (1987). Temperature dependence of the oxygen isotopic fractionation between diatom silica and water. Earth and Planetary Science Letters, 84, 69-74.

Kiefer, T., Sarnthein, M., Erlenkeuser, H., Grootes, P. M., \& Roberts, A. P. (2001). North Pacific response to millennial-scale changes in ocean circulation over the last 60 kyr. Paleoceanography, 16, 179-189.

Kipphut, G. W. (1990). Glacial meltwater input to the Alaska Coastal Current: evidence from oxygen isotope measurements. Journal of Geophysical Research Oceans, 95, 5177-5181.Leng, M. J., \& Sloane, H. J. (2008). Combined oxygen and silicon isotope analysis of biogenic silica. Journal of Quaternary Science, 23, 313-319.

Leschinski, C. H. (2019). MonteCarlo: Automatic Parallelized Monte Carlo Simulations. R package version 1.0.6. https://CRAN.R-project.org/package=MonteCarlo.

Lesnek, A. J., Briner, J. P., Baichtal, J. F., \& Lyles, A. S. (2020). New constraints on the last deglaciation of the Cordilleran Ice Sheet in coastal Southeast Alaska. Quaternary Research, 96, 140-160.

Lisiecki, L. E., \& M. E. Raymo (2005). A Pliocene-Pleistocene stack of 57 globally distributed benthic $\delta^{18} \mathrm{O}$ records. Paleoceanography, 20, PA1003, doi:10.1029/2004PA001071.

Liu, W., \& Hu, A. (2015) The role of the PMOC in modulating the deglacial shift of the ITCZ. Climate Dynamics, 45, 3019-3034.

Lopes, C., \& Mix, A. C. (2009). Pleistocene megafloods in the northeast Pacific. Geology, 37, 79-82.

Lynch-Stieglitz, J., Schmidt, M. W., Henry, L. G., Curry, W. B., Skinner, L. C., Mulitza, S., Zhang, R., \& Chang, P. (2014). Muted change in Atlantic overturning circulation over some glacial-aged Heinrich events. Nature Geoscience, 7, 144-150.

Maier, E., Méheust M., Abelmann A., Gersonde R., Chapligin B., Ren J., Stein R., MeyerH. , \& Tiedemann, R. (2015). Deglacial subarctic Pacific surface water hydrography and nutrient dynamics and links to North Atlantic climate variability and atmospheric $\mathrm{CO}_{2}$. Paleoceanography, 30, 949-968.

Maier, E., Zhang, X., Abelmann, A., Gersonde, R., Mulitza, S., Werner, M., Méheust, M., Ren, J., Chapligin, B., Meyer, H., Stein, R., Tiedemann, R., \& Lohmann, G. (2018). North Pacific freshwater events linked to changes in glacial ocean circulation. Nature, 559, 241-245.

Marret, F., de Vernal, A., McDonald, D., \& Pedersen, T. (2001). Middle Pleistocene to Holocene palynostratigraphy of ODP Site 887 in the Gulf of Alaska, northeast North Pacific. Canadian Journal of Earth Sciences. 38, 373-386.

Maslin, M. A., Shackleton, N. J., \& Pflaumann, U. (1995), Surface water temperature, salinity, and density changes in the northeast Atlantic during the last 45,000 years: Heinrich events, deep water formation, and climatic rebounds. Paleoceanography, 10, 527-544.

Max, L., Riethdorf, J.-R., Tiedemann, R., Smirnova, M., Lembke-Jene, L., Fahl, K., Nürnberg, D., Matul, A., \& Mollenhauer, G. (2012). Sea surface temperature variability and sea-ice extent in the subarctic northwest Pacific during the past 15,000 years, Paleoceanography. 27, PA3213.

McDonald, D. W. (1997). The Late Quaternary history of primary productivity in the subarctic east Pacific. M.Sc. Thesis, University of British Columbia, Canada.

478 McDonald, D., Pedersen, T. F., \& Crusius, J. (1999). Multiple late Quaternary episodes of exceptional diatom production in the Gulf of Alaska. Deep-Sea Research II, 46, 2993-3017.

480 Menicucci, A. J., Spero, H. J., Matthews, J., Parikh, S. J. (2017). Influence of exchangeable oxygen on biogenic silica oxygen isotope data. Chemical Geology, 466, 710-721.

Menviel, L., England M. H., Meissner K. J., Mouchet A., \& Yu, J. (2014). Atlantic-Pacific seesaw and its role in outgassing $\mathrm{CO}_{2}$ during Heinrich events. Paleoceanography, 29, 58-70. 
Metcalfe, B., Feldmeijer, W., \& Ganssen, G. M. (2019). Oxygen isotope variability of planktonic foraminifera provide clues to past upper ocean seasonal variability. Paleoceanography and Paleoclimatology, 34, 374-393.

Moschen, R., Lücke, A., \& Schleser, G. (2005). Sensitivity of biogenic silica oxygen isotopes to changes in surface water temperature and palaeoclimatology. Geophysical Research Letters, 32, L07708, doi:10.1029/2004GL022167.

Moschen, R., Lücke, A., Parplies, J., Radtke, U., \& Schleser, G.H. (2006). Transfer and early diagenesis of biogenic silica oxygen isotope signals during settling and sedi- mentation of diatoms in a temperate freshwater lake (Lake Holzmaar, Germany). Geochimica et Cosmochimica Acta, 70, 4367-4379.

North Greenland Ice Core Project members. (2004). High-resolution record of Northern Hemisphere climate extending into the last interglacial period. Nature, 431, 147-151.

Okazaki, Y., Timmermann, A., Menviel, L., Harada, N., Abe-Ouchi, A., Chikamoto, M.O., Mouchet, A., \& Asahi, H. (2010). Deepwater Formation in the North Pacific During the Last Glacial Termination. Science, 392, 200-204.

Praetorius, S. K., \& Mix, A. C. (2014). Synchronization of North Pacific and Greenland climates preceded abrupt deglacial warming. Science, 345, 444-448.

Praetorius, S. K., Mix, A. C., Walczak, M. H., Wolhowe, M. D., Addison, J. A., \& Prahl, F. G. (2015). North Pacific deglacial hypoxic events linked to abrupt climate warming. Nature, 527, 362-366.

R Core Team (2020). R: A language and environment for statistical computing. R Foundation for Statistical Computing, Vienna, Austria. URL https://www.R-project.org/.

Rea, D. K., Basov, I. A., Janacek, T. R., et al., 1993. Proceedings of the Ocean Drilling Program, Initial Report., ODP. doi:10.2973/odp.proc.ir.145.110.1993.

Rae, J. W. B., Sarnthein, M., Foster, G. L., Ridgwell, A., Grootes, P. M., \& Elliott T. (2014). Deep water formation in the North Pacific and deglacial $\mathrm{CO}_{2}$ rise. Paleoceanography, 29, 645-667.

Rasmussen, T. L., Oppo, D. W., Thomsen, E., \& Lehman, S. J. (2003). Deep sea records from the southeast Labrador Sea: Ocean circulation changes and ice-rafting events during the last 160,000 years. Paleoceanography, 18, 1018, doi:10.1029/2001PA000736.

Romero, O. E., Swann, G. E. A., Hodell, D. A., Helmke, P., Rey, D., \& Rubio, B. (2011). A highly productive Subarctic Atlantic during the Last Interglacial and the role of diatoms. Geology, 39, 1015-1018.

Sancetta, C., Heusser, L., Labeyrie, L., Sathy Naidu, A., \& Robinson, S. W. (1985). Wisconsin - Holocene paleoenvironment of the Bering Sea: evidence from diatoms, pollen, oxygen isotopes and clay minerals. Marine Geology, 62, 55-68.

Schiff, C. J., Kaufman, D. S., Wolfe, A. P., Dodd, J., \& Sharp, Z. (2009). Late Holocene storm-trajectory changes inferred from the oxygen isotope composition of lake diatoms, south Alaska. Journal of Paleolimnology, 41, 189-208.

Schmidt, M., Botz, R., Stoffers, P., Anders, T., \& Bohrmann, G. (1997). Oxygen isotopes in marine diatoms: a comparative study of analytical techniques and new results on the isotopic composition of recent marine diatoms. Geochimica et Cosmochimica Acta, 61, 2275-2280.

Schmidt, M., Botz, R., Rickert, D., Bohrmann, G., Hall, S.R., \& Mann, S., (2001). Oxygen isotope of marine diatoms and relations to opal-A maturation. Geochimica et Cosmochimica Acta 65, 201-211.

Seidov, D., Baranova O. K., Boyer T. P., Mishonov A. V., \& Parsons A. R. (2016). Northern North Pacific Regional Climatology, Regional Climatology Team, NOAA/NCEI, (www.nodc.noaa.gov/OC5/regional_climate/nnp-climate), dataset doi:10.7289/V5KK98TQ.

Shemesh, A., Burckle, L. H., \& Hays, J. D. (1995). Late Pleistocene oxygen isotope records of biogenic silica from the Atlantic sector of the Southern Ocean. Paleoceanography, 10, 179-196.

Shemesh, A., Hodell, D., Crosta, C., Kanfoush, S., Charles, C., \& Guilderson, T. (2002). Sequence of events during the last deglaciation in Southern Ocean sediments and Antarctic ice cores. Paleoceanography, 17, 1056, doi:10.1029/2000PA000599. 
Sima, A., Paul, A., Schulz, M., \& Oerlemans, J. (2006). Modeling the oxygen-isotopic composition of the North American Ice Sheet and its effect on the isotopic composition of the ocean during the last glacial cycle. Geophysical Research Letters, 33, L15706, doi:10.1029/2006GL026923.

Swann, G. E. A. (2010). Salinity changes in the North West Pacific Ocean during the late Pliocene/early Quaternary from 2.73 Ma to 2.52 Ma. Earth and Planetary Science Letters, 297, 332-338.

Swann, G. E. A., \& Leng, M. J. (2009). A review of diatom $\delta^{18} \mathrm{O}$ in palaeoceanography. Quaternary Science Reviews, 28, 384-398.

Swann, G .E .A., Maslin, M. A., Leng, M. J., Sloane, H. J., \& Haug, G. H. (2006). Diatom $\delta^{18}$ O evidence for the development of the modern halocline system in the subarctic northwest Pacific at the onset of major Northern Hemisphere glaciation. Paleoceanography, 21, PA1009, doi:10.1029/2005PA001147.

Swann, G. E. A., Leng, M. J., Sloane, H. J., Maslin, M. A., \& Onodera, J. (2007). Diatom oxygen isotopes: evidence of a species effect in the sediment record. Geochemistry Geophysics Geosystems, 8, Q06012, doi:10.1029/2006GC001535.

Swann, G. E. A., Leng, M. J., Sloane, H. J., \& Maslin, M. A. (2008). Isotope offsets in marine diatom $\delta^{18} \mathrm{O}$ over the last $200 \mathrm{ka}$. Journal of Quaternary Science, 23, 389-400.

Swann, G. E. A., Pike, J., Snelling, A. M., Leng, M. J., \& Williams, M. C., 2013. Seasonally resolved diatom $\delta^{18} \mathrm{O}$ records from the west Antarctic Peninsula over the last deglaciation. Earth and Planetary Science Letters, 364, 12-23.

Takahashi, K. (1986). Seasonal fluxes of pelagic diatoms in the subarctic Pacific, 1982-1983. Deep Sea Research Part A. Oceanographic Research Papers, 33, 1225-1251.

Taylor, M. A., Hendy, I. L., \& Pak, D. K. (2014). Deglacial ocean warming and marine margin retreat of the Cordilleran Ice Sheet. Earth and Planetary Science Letters, 403, 89-98.

Taylor, B. J., Rae, J. W. B,. Gray, W. R., Darling, K. F., Burke, A., Gersonde, R., Abelmann, A., Maier, E., Esper, O., \& Ziveri, P. (2018). Distribution and ecology of planktic foraminifera in the North Pacific: Implications for paleo-reconstructions. Quaternary Science Reviews, 191 256-274.

Waelbroeck, C., Labeyrie, L., Michela, E., Duplessy, J. C., McManus, J. F., Lambeck, K., Balbon, E., Labracherie, M. (2002). Sea-level and deepwater temperature changes derived from benthic foraminifera isotopic records. Quaternary Science Review, 21, 295-305.

Wood, S. N. (2017). Generalized Additive Models: An Introduction with R (2nd edition). Chapman and Hall/CRC. 